\title{
Dampak Potensi Pariwisata Terhadap Kualitas Air Danau Beratan
}

\author{
Riyadh $^{1 *}$, I Gede Astra Wesnawa ${ }^{1}$, I Putu Ananda Citra ${ }^{1}$
}

${ }^{1}$ Program Studi Pendidikan Geografi, Jurusan Geografi, Universitas Pendidikan Ganesha, Indonesia

\author{
A R T I C L EI N F O \\ Article history: \\ Received \\ Received in revised \\ form \\ Accepted \\ Available online \\ Kata Kunci: \\ Dampak Potensi \\ Pariwisata; Kualitas \\ Air Danau, \\ Pencemaran Limbah \\ Keywords: \\ Tourism Potency \\ Impact; Lake Water \\ Quality; Waste \\ Pollution
}

\begin{abstract}
A B S T R A K
Penelitian ini bertujuan untuk mengetahui potensi pariwisata dan dampak pariwisata di Danau Beratan, Desa Candikuning, Kecamatan Baturiti, Kabupaten Tabanan. Penelitian ini menggunakan metode analisis deskriptif kualitatif dari perspektif geografi pariwisata yang dianalisis dengan pendekatan kelingkungan. Sampel yang diambil meliputi empat saluran limbah pembuangan dan air Danau Beratan. Pengumpulan data menggunakan metode observasi, metode uji laboratorium, metode teknik skoring dan studi pustaka. Hasil penelitian ini menujukan bahwa potensi pariwisata yang diukur melalui variabel objek wisata internal dan ekternal di Danau Beratan memiliki potensi sedang dimana karakteristik objek wisata Danau Beratan yang menjadi faktor pendorong dan penghambat adalah seimbang atau sama. Sedangkan, hasil penelitian dari uji laboratorium secara keseluruhan masing-masing sampel air menyatakan bahwa kualitas air masih normal. Ini berarti bahwa pencemaran kualitas air yang berasal dari bahan-bahan kimia yang terdapat di sekitar kawasan objek Danau Beratan masih berada pada batas normal dan belum menunjukan bahwa air mengalami tingkat pencemaran yang tinggi. Sedangkan dari hasil pemeriksaan bakteriologis menunjukan hasil yang berbanding
\end{abstract} terbalik dengan hasil pemeriksaan kimia maupun fisikanya. Dari hasil pemeriksaan bakteriologis menujukan bahwa air mengalami kontaminasi bakteriologis yang disebabkan oleh adanya bakteri coliform dan tinja. Konsentrasi pencemaran oleh bakteri coliform ini berpusat pada air Danau yang berada dekat pada aktivitas manusia yaitu titik barat dari danau tersebut yang merupakan sumber aktifitas manusia yang sangat memungkinkan memberikan kontribusi secara langsung kepada kualitas air dalam bentuk limbah yang terbuang langsung ke air Danau Beratan sehingga air danau mengalami pencemaran.

\section{A B S T R A C T}

This study aims to determine the tourism potential and the impact of tourism in Lake Beratan, Candikuning Village, Baturiti District, Tabanan Regency. This study uses descriptive qualitative analysis methods from perspektif geography which is analyzed by the environmental approach. Samples taken included four sewerage channels and Beratan Lake. Data collection using the method of observation, laboratory test methods, scoring techniques and literature study. The results of this study show that the tourism potential measured through internal and external tourist attraction variables in Lake Beratan has moderate potential where the characteristics of Lake Beratan attractions that are driving and inhibiting factors are balanced or equal. Meanwhile, the results of research from laboratory tests Overall, each water sample stated that the water quality was normal. This means that water quality pollution from chemicals found in the vicinity of the Lake Beratan object is still within normal limits and has not yet shown that the water is experiencing a high level of pollution. While the results of bacteriological examination show the results that are inversely proportional to the results of chemical and physical examination. From the results of bacteriological examination showed that the water experienced bacteriological contamination caused by the presence of coliform and fecal bacteria. The concentration of pollution by coliform bacteria is centered on Lake water which is close to human activities, namely the western point of the lake which is a source of human activity that is very possible to contribute directly to water quality in the form of waste that is discharged directly into Lake Beratan so that lake experiencing pollution. 


\section{Pendahuluan}

Pulau Bali merupakan sebuah pulau kecil di antara ribuan pulau yang berada di indonesia. Berdasarkan BPS (2018) secara geografis Pulau Bali terletak pada $8^{\circ} 3^{\prime} 40^{\prime \prime}-8^{\circ} 50^{\prime} 48^{\prime \prime}$ Lintang Selatan dan $114^{\circ} 25^{\prime} 53^{\prime \prime}$ - $115^{\circ} 42^{\prime} 40^{\prime \prime}$ Bujur Timur dengan batas fisik, yaitu utara: Laut Bali, timur: Selat Lombok (Provinsi Nusa Tenggara Barat), selatan: Samudera Indonesia, dan barat: Selat Bali (Provinsi Jawa Timur). Secara administrasiPulau Bali terbagi menjadi satu kota, yaitu Kota Denpasar yang merupakan Ibukota Provinsi serta delapan kabupaten yang meliputi Kabupaten Badung, Gianyar, Bangli, Klungkung, Karangasem, Buleleng, Jembrana, dan Tabanan. Luas total wilayah Pulau Bali adalah 5.634,40 ha dengan panjang pantai mencapai $529 \mathrm{~km}^{2}$. Dilihat dari segi wilayahnya, Pulau Bali memiliki kondisi fisik yang sama dengan daerah lain berupa pulau. Pulau Bali yang biasa disebut dengan pulau dewata, pulau seribu pura, atau pulau surga karena keindahan alam yang eksotis, keagungan karya seninya, serta kebudayaan yang khas dan menarik, memiliki potensi dibidang pertanian, pariwisata serta destinasi keunikan dan budaya.

Dilihat dari kondisi geografis Pulau Bali di atas, Pulau Bali memiliki objek wisata yang sangat beragam, baik wisata alam, wisata budaya, dan wisata bahari. Menurut data BPS tahun (2018), Pulau Bali memiliki sekitar 54 lokasi objek wisata yang tersebar di delapan kabupatenya (Somantri, 2015). Salah satu objek wisata alam yang menarik dan banyak di kunjungi wisatawan di Pulau Bali yaitu Danau Beratan. Danau Beratan merupakan salah satu Danau di Pulau Bali yang terletak di kawasan Bedugul, Desa Candikuning Kecamatan Baturiti, Kabupaten Tabanan. Danau dengan luas $3,85 \mathrm{~km}^{2}$, panjang danau $7,5 \mathrm{~km}^{2}$ dan lebar $2,0 \mathrm{~km}^{2}$, kedalaman maksimum sekitar 20 m serta berada di ketinggian 1231 meter di atas permukaan laut tersebut memiliki karakteristik berupa danau kaldera dengan sistem perairan yang tertutup (Hehanussa, 2009). Lingkungan sekitar Danau Beratan lebih di dominasi oleh keberadaan kawasan wisata, terutama kawasan bedugul dan Pura Ulun Danau Beratan, serta beberapa akomodasi yang berada di sekitaran Danau beratan yang dilengkapi beberapa fasilitas wahana permainan air, seperti perahu motor (speed boat), boat atap, sampan dayung, dan pedal boat untuk mengelilingi danau, pedagang, hotel dan restoran.

Danau Beratan yang memiliki pengunjung tertinggi di antara ketiga Danau di Pulau Bali. Berikut daftar tabel pengunjung wisatawan domestik maupun mancanegara Danau di Pulau Bali tahun 2017.

Tabel 1. Jumlah Kunjungan Wisatawan Danau Beratan

\begin{tabular}{llll}
\hline Danau & $\begin{array}{l}\text { Domestik } \\
\text { (orang) }\end{array}$ & $\begin{array}{l}\text { Mancanegara } \\
\text { (orang) }\end{array}$ & $\begin{array}{l}\text { Jumlah Pengunjung } \\
\text { (orang) }\end{array}$ \\
\hline Beratan & 557.684 & 336.821 & 894.505 \\
\hline Batur & 300.933 & 285.578 & 586.511 \\
\hline Buyan & 6.633 & 2.662 & 9.295 \\
\hline Tamblingan & 7.808 & 8.499 & 16.307 \\
\hline & Sumber: Dinas Pariwisata Pemerintah Provinsi Bali, 2017
\end{tabular}

Berdasarkan data tersebut menunjukkan bahwa kunjungan wisatawan tertinggi yaitu kunjungan wisata di Danau Beratan Kecamatan Baturiti Kabupaten Tabanan. Banyaknya pengunjung wisatawan tersebut dan di dukungnya beberapa fasilitas wahana permainan air seperti perahu motor (speed boat), boat atap, sampan dayung, pedal boat, pedagang dan akomodasi seperti hotel dan restoran yang ada di Danau Beratan, potensi limbah yang akan dihasilkan oleh sektor pariwisata akan semakin meningkat sehingga akan meningkatkan pencemaran di Danau Beratan. Banyaknya wisatawan domestik maupun mancanegara yang berkunjung dan menikmati wahana transportasi air perahu motor (speedboat), boat di Danau Beratan, tumpahan minyak yang dihasilkan dari wahana transportasi air sudah terjadi. Kunjungan wisatawan domestik maupun mancanegara juga lebih berpotensi menigkatkan pencemaran ke Danau karena semakin banyak yang menikmati wahana transportasi air. Menurut Soerjani dkk. (2005) dalam Faisal (2019), kebutuhan akan air bersih oleh manusia semakin meningkat seiring dengan 
bertambahnya jumlah penduduk. Kenyataan yang terjadi sekarang ini, kualitas air semakin menurun serta mengalami penyimpangan tatanan sebagai dampak dari eksploitasi secara berlebihan dan perilaku mahluk hidup terutama aktivitas manusia yang tidak memperhatikan aspek lingkungan, sehingga tidak mencapai peruntukan dan mutunya bagi berbagai segi kehidupan. Berikut kejadian tumpahnya minyak dari wahana transpotrasi air di Danau Beratan.

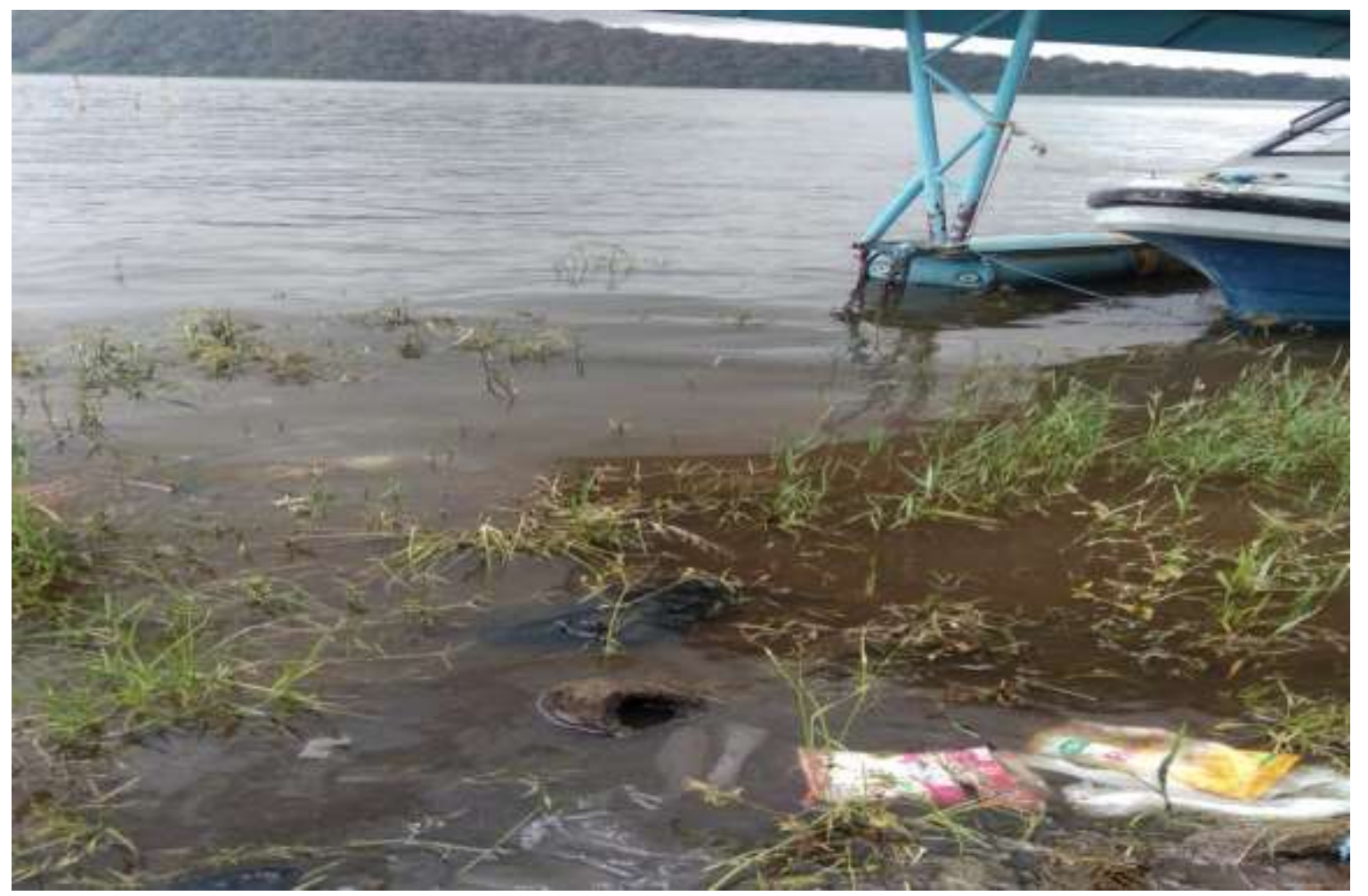

Gambar 1. Tumpahan Minyak dari Speed Boat ke Danau Beratan

(Sumber: Dokumentasi, 2019)

Tumpahnya minyak dari perahu motor (speed boat) tersebut mengakibatkan timbulnya berbagai masalah, seperti pencemaran lingkungan, pendangkalan danau dan erosi (Rahadiani, 2019). Menurut Manumudhita (2002), Bappeda Propinsi Bali tahun 2002 dan Studi Konservasi Perlindungan Danau Beratan di Kabupaten Tabanan dan Danau Tamblingan di Kabupaten Buleleng oleh Balai Wilayah Sungai Bali-Penida Direktorat Jenderal Sumber Daya Air Kementerian Pekerjaan Umum RI tahun 2012, Danau Beratan sudah tercemar minyak dan lemak sebesar 14,66 mg/l air diakibatkan oleh beroperasinya perahu motor (speed boat) di kawasan ini. Sejalan dengan penelitian sebelumnya yang diteliti oleh Malia (2017) tentang Studi Pengelolaan Limbah Bahan Berbahaya Dan Beracun Khusus Minyak/Oli Bekas Pada Bengkel Motor Di kota Makasar. Bahwa tercemarnya air akibat Minyak/Oli akan berdampak besar pada kualitas air Danau tersebut. Tujuan penelitian ini adalah menganalisis potensi Pariwisata di Danau Beratan dan dampak pariwisata terhadap pencemaran air di Danau Beratan Kecamatan Baturiti, Kabupaten Tabanan.

\section{Metode}

Rancangan penelitian yang digunakan adalah rancangan penelitian deskriptif kualitatif dengan analisis kelingkungan. Daerah yang dijadikan sebagai lokasi dalam penelitian ini adalah Desa Candikuning. Objek pada penelitian ini adalah Danau Beratan seperti terlihat pada Gambar 2. Sedangkan yang menjadi subjek penelitian adalah limbah yang dihasilkan oleh perahu motor (speed boat), restoran dan hotel yang berada di kawasan Danau Beratan. Sampel menggunakan 4 (empat) saluran pembuangan limbah air di Danau Beratan dan sampel diambil secara acak. 


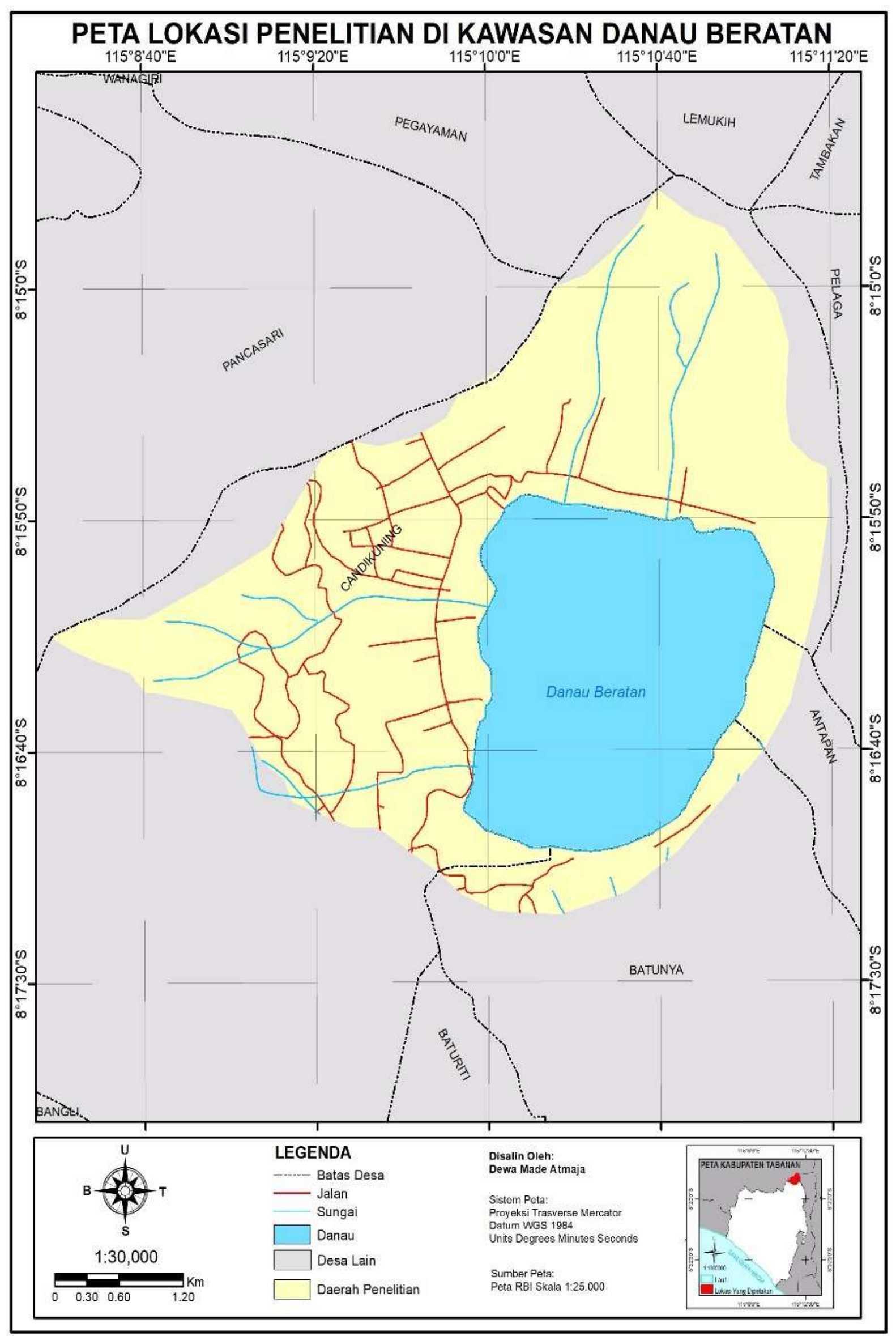

Gambar 3. Kawasan Danau Beratan 
Data dikumpulkan dengan metode observasi, dokumentasi, uji laboratorium. dan teknik skoring. Sebelum dilakukan analisis maka dilakukan pengolahan data terlebih dahulu. Adapun pengolahan data dalam penelitian ini menggunakan interval kelas untuk memperoleh data internal dan eksternal. Rumus yang digunakan untuk menentukan data internal dan eksternal adalah sebagai berikut:

Total skor pada variabel potensi obyek wisata dan total skor pada variabel potensi kawasan, kemudian diklasifikasikan yaitu klasifikasi tinggi sedang dan rendah. Untuk mengetahui penilaian potensi gabungan dengan cara menggabungkan total skor dari semua variabel yang dijumlahkan. Klasifikasi dilakukan dengan menggunakan interval kelas yang ditentukan dengan rumus Sturges.

$$
\begin{aligned}
& \qquad k=\frac{a-b}{u} \\
& k=\text { Internal } \\
& a=\text { Nilai Skor Tertinggi } \\
& b=\text { Nilai Skor Terendah } \\
& u=\text { jumlah Kelas }
\end{aligned}
$$

(1) Menentukan skor terendah dan skor tertinggi dari keseluruhan alternatif jawaban.

Skor tertinggi $=($ nilai tertinggi $\mathrm{x}$ jumlah variabel $)$

Skor terendah $=($ nilai terendah $\mathrm{x}$ jumlah skor relative $)$

Keterangan :

Nilai tertinggi $=168$, nilai terendah $=56$

Keterangan :

Nilai tertinggi $=56 \times 3=168$

Nilai terendah $=14 \times 4=56$

(2) Menentukan jarak interval

Interval $=($ nilai minimal + jumlah skor $): 3$

Interval $=(56-37,3)=93,3$

$(93,3-37,3)=130,6$

$(130,6-37,3)=167,9$

(3) Kategori

56-93,3= Kelas Potensi Rendah

93,3-130,6 = Kelas Potensi Sedang

130,6-167,6 = Kelas Potensi Tinggi

Data yang diperoleh dari hasil observasi, wawancara, uji laboratorium dan teknik skoring kemudian dianalisis. Teknik analisis dalam penelitian ini akan dilakukan secara deskripstif kualitatif untuk mengetahui Dampak Potensi Pariwisata Terhadap Kualitas Air di Danau Beratan Kecamatan Baturiti Kabupaten Tabanan.

\section{Hasil dan pembahasan}

\section{Potensi Pariwisata di Danau Beratan Kecamatan Baturiti Kabupaten Tabanan}

Perkembangan fasilitas pendukung pariwisata Danau Beratan bisa dilihat dari banyaknya infrastruktur penambahan fasilitas wisata air yang dulunya mungkin dalam jumlah yang sangat terbatas serta manajemen pengelolan yang kurang baik sehingga dulu objek wisata ini tidak begitu memperlihatkan perkembangannya seperti sekarang. Penelitian ini sejalan dengan penelitian Grace (2013) Kajian Pencemaran Lingkungan Perairan Akibat Limbah Domestik di Danau Sentani Kabupaten Jayapura Provinsi Papua.

Perkembangan yang ditunjukan pada saat ini cukup signifikan mulai dari penambahan fasilitas pendukung pariwisata seperti perluasan areal parkir, penataan taman, pembangunan 
arshop yang saat ini jumlahnya mencapai 32 buah arshop yang dibuat secara los memanjang. Selain itu terdapat 1 buah restauran yang cukup besar, serta beberapa restauran lainnya yang berada di sepanjang jalan kawasawan objek wisata danau beratan. dan juga terdapat 20 buah dayung sampan, 15 buah sepeda air serta 30 unit speedboat. Dari masing-masing fasilitas tersebut khususnya fasilitas wisata air yang ditawarkan memiliki tarif penyewaan yang berbeda-beda. Potensi pariwisata yang berada di danau beratan memiliki potensi yang cukup, dilihat dari penilaian variabel-variabel, Penilaian variabel penelitian obyek wisata menghasilkan suatu analisis yang matematis, maka pengamatan yang semula bersifat kualitatif kemudian dikonversikan ke dalam angka matematis dengan metode skoring. Metode skoring ini digunakan empat variabel, yaitu daya tarik obyek wisata, aksesibilitas obyek wisata, variabel sarana pokok kegiatan wisata dan sarana pelengkap kegiatan wisata. Setiap variabel diberi bobot yang berbeda untuk membedakan besar pengaruh setiap variabel dalam menarik wisatawan. Nilai skor ditentukan untuk membedakan pengaruh antara beberapa kriteria dalam suatu variabel penelitian. Potensi pariwisata Danau Beratan memiliki potensi yang sedang karna memliki nilai skor 101.3 dimana karakteristik objek wisata Danau Beratan yang menjadi faktor pendorong dan penghambat adalah seimbang atau sama.

\section{Dampak Pariwisata terhadap Kualitas Air Danau Beratan}

Dampak pariwisata dalam penelitian ini adalah tingkat konstribusi limbah yang ditimbulkan oleh adanya kegiatan pariwisata yang dintunjang oleh adanya perkembangan fasilitas-fasilitas pendukung pariwisata yang ada di Danau Beratan seperti bangunan hotel, restauran, para pedagang, speedboat serta fasilitas lainnya. Serta adanya pengembangan wisata air Danau Beratan, kawasan ini pun tidak luput dari dampak yang di timbulkan. Berikut gambar beroperasi speedboat dikawasan Danau Beratan.

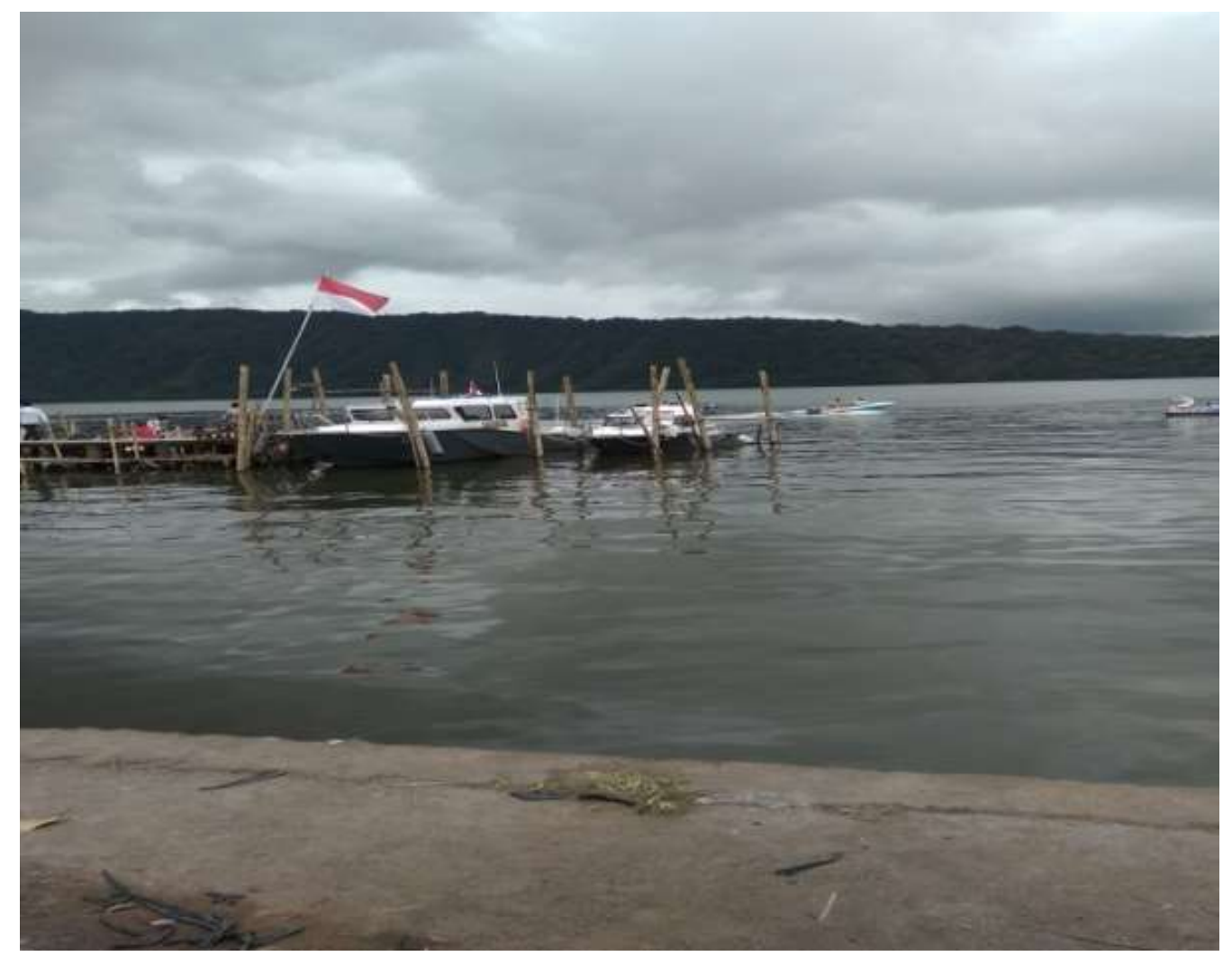

Gambar 3. Speedboat yang beroperasi di Danau Beratan

(Sumber: Dokumentasi, 2019)

Dapat dilihat pada Gambar 3, maka tampak itu merupakan salah satu pencemaran secara langsung ke badan air yang dilakukan oleh fasilitas speedboat yang berjalan diatas air danau, 
dan buangan dari bahan bakarnya mengakibatkan penurunan terhadap kualitas air Danau Beratan yang tentunya ini merupakan dampak negatif yang ditimbulkan. Adapun dampak negatif lainnya yaitu yang ditimbulkan dari adanya perkembangan fasilitas pendukung pariwisata dikawasan ini seperti misalnya industri perhotelan dan restouran serta pedagangpedagang makanan yang ada di sepanjang kawasan objek wisata Danau Beratan akan menghasilkan limbah cukup tinggi. Tingginya konstribusi lombah dalam mencemari ar Danau Beratan disebabkan karena pembuangan limbah hasil industri dihubungkan langsung kearah danau, hal ini jelas akan sangat berpengaruh negatif terhadap kualitas air danau. Penelitian ini juga sejalan dengan penelitian Malia (2017) Studi Pengelolaan Limbah Bahan Berbahaya Dan Beracun Khusus Minyak/Oli Bekas Pada Bengkel Motor Di kota Makasar. Penelitian ini juga sejalan dengan penelitiam Abdurrahman (2006) bahwa limbah yang dihasilkan dari minyak dan lemak merupakan limbah cair dan limbah cair tersebut akan selalu larut, berpindah kecuali ditempatkan di wadah yang berbeda.

Berdasarkan analisis data kualitas air Danau Beratan tahun 2018 ( Tabel 7) dan di dukung oleh analisis potensi pariwisata Danau Beratan yang tergolong kelas sedang maka, kualitas air Danau Beratan tergolong sedang karena sudah terkontaminasi oleh baktreriologis yaitu bakteri coli serta coliform tinja. Konsentrasi bakteri coli yang terdapat pada air Danau Beratan yaitu berkisar pada $2-240 \mathrm{MPN} / 100 \mathrm{ML}$ sedangkan konsentrasi coliform tinja mencpai 38 MPN/200 ML. Hal ini telah menunjukan bahwa air Danau Beratan sudah tercemar oleh limbah dari hasil kegiatan pariwisata yang ditunjang oleh berkembangannya fasilitas pendukung pariwisata yang ada di kawasan tersebut. Penelitian ini sejalan dengan Engelen (1997) yang berjudul Limnological Study of Logo Di Braies (Pragser Wildsee) Dolomite. mendeskripsikan bahwa fluktuasi air Danau rerata Tahunan Sebesar 1,2 meter.

Analisis kualitas air Danau Beratan menunjukan bahwa kualitas air danau di tinjau dari aspek fisik saperti bau, TDS, kekeruhan, rasa, suhu, warna berada pada batas normal yang artinya bahwa air tidak begitu mengalami pencemaran tidak berbau, tidak berasa dan tidak berwarna. Apabila dilihat dari aspek kimia baik itu kimia anorganik maupun organik juga berada pada batas normal walaupun $\mathrm{pH}$ air rendah yaitu mencapai $5 \mathrm{Mg} / \mathrm{L}$ sedangkan kadar maksimal pH air yaitu 6,59 $\mathrm{Mg} / \mathrm{L}$ namun secara keseluruhan dari hasil pemeriksaan masingmasing sampel air menyatakan bahwa kualitas air masih normal. Ini berati bahwa pencemaran kualitas air yang yang berasal dari nahan-bahan kimia yang terdapat di sektiar objek wisata Danau Beratan masih berada batas normal dan belum menunjukan bahwa air mengalami tingkat pencemaran tinggi.

Sedangkan hasil pemeriksaan bakteriologis menunjukan hasil yang berbanding terbalik dengan hasil pemeriksaan kimia maupun fisikanya. Dari hasil pemeriksaan bakteriologis yang disebabkan oleh adanya coliform dan coliformh tinja. Konsentrasi pencemaran oleh bakteri coliform ini berpusat pada air Danau yang berada dekat pada aktifitas manusia yaitu titik barat dari danau tersebut yang merupakan sunber aktifitas manusia yang sangat memungkinkan memberikan konstribusi secara langsung kepada kualitas air dalam bentuk limbah yang terbuang langsung ke air Danau Beratan sehingga air danau menglami pencemaran.

Semakin banyak aktifitas manusia yang menimbulkan adanya bakteri coli atau coliform tinja maka aktifitas air danau semakin beresiko apabila digunakan sebagai pemenuhan air bersih bagi masyarakat sekitar. Maka dari itu diperlukan kesadaran dari masyarakat setempat maupun wisatawan yang berkunjung ke objek wisata Danau Beratan untuk menjaga kelestarian lingkungan khususnya menjaga kualitas air yang ada di Danau Beratan agar kualitasnya tetap terjaga dan bisa digunakan untuk keperluan pemenuhan air bersih. Seperti yang dikemukakan oleh Anggreswari (2018:27) bahwa untuk menjaga kelestarian lingkungan dalam pengelolaan objek wisata perlu penerapan Tri Hita Karana dalam unsur alam semesta dengan cara menjaga kawasan objek wisata agar tetap terjaga kebersihannya dengan melibatkan pelaku wisata dan aparat yang bertugas. Selain itu partisipasi masyarakat juga penting, seperti yang dikemukakan oleh Frasawi (2018) bahwa partisipasi masyarakat dalam pengembangan objek wisata dapat terwujud apabila 3 faktor terpenuhi yaitu: (1) kesadaran; (2) kemampuan; (3) kesempatan 
berpartisipasi. Keseluruhan hasil pemeriksaan ini dilakukan telah mengacu pada PERMENKES NO.146 / MENKES / PE / IX / 1990 tentang kualitas air bersih.

Tabel 7. Data Kualitas Air Danau Beratan

\begin{tabular}{|c|c|c|c|c|c|c|}
\hline No & Parameter & Satuan & $\begin{array}{c}\text { Kadar } \\
\text { maksimal }\end{array}$ & $\begin{array}{l}\text { Sampel } \\
\text { barat }\end{array}$ & $\begin{array}{l}\text { Sampel } \\
\text { tengah }\end{array}$ & $\begin{array}{l}\text { Sampel } \\
\text { timur }\end{array}$ \\
\hline (1) & (2) & (3) & (4) & (5) & (6) & (7) \\
\hline A. & FISIKA & & & & & \\
\hline 1. & Bau & - & - & Tidak berbau & Tidak berbau & Tidak berba \\
\hline 2. & TDS & $\mathrm{Mg} / \mathrm{L}$ & 1500 & 26 & 28 & 25 \\
\hline 3. & Kekeruhan & Skala NTU & 25 & 0.21 & 0.21 & 0.23 \\
\hline 4. & Rasa & - & - & Tidak berasa & Tidak berasa & Tidak beras \\
\hline 5. & Suhu & ${ }^{0} \mathrm{C}$ & Suhu udara $\pm 3^{0} \mathrm{C}$ & 25 & 25 & 25 \\
\hline 6. & Warna & Skala NTU & 50 & Tidak berwarna & Tidak berwarna & Tidak berwa \\
\hline
\end{tabular}

B. KIMIA

\begin{tabular}{|c|c|c|c|c|c|c|}
\hline \multicolumn{7}{|c|}{ ANORGANIK } \\
\hline 1. & Besi & $\mathrm{Mg} / \mathrm{L}$ & 1 & 0.01 & 0.00 & 0.00 \\
\hline 2. & Florida & $\mathrm{Mg} / \mathrm{L}$ & 1.5 & 0.00 & 0.00 & 0.00 \\
\hline 3. & Kesadahan & $\mathrm{Mg} / \mathrm{L}$ & 500 & 8.81 & 9.52 & 9.52 \\
\hline 4. & Klorida & $\mathrm{Mg} / \mathrm{L}$ & 600 & 12 & 10 & 10 \\
\hline 5. & Mangan & $\mathrm{Mg} / \mathrm{L}$ & 0.5 & 0.04 & 0.04 & 0.04 \\
\hline 6. & Nitrat sbg. N & $\mathrm{Mg} / \mathrm{L}$ & 10 & 0.24 & 0.15 & 0.13 \\
\hline 7. & Nitrit sbg. N & $\mathrm{Mg} / \mathrm{L}$ & 1 & 0.00 & 0.00 & 0.00 \\
\hline 8. & $\mathrm{pH}$ & $\mathrm{Mg} / \mathrm{L}$ & $6.5-9$ & 5 & 5 & 5 \\
\hline 9. & Sulfat & $\mathrm{Mg} / \mathrm{L}$ & 400 & 2.21 & 2.50 & 2.31 \\
\hline \multicolumn{7}{|c|}{ ORGANIK } \\
\hline 1. & $\begin{array}{l}\text { Zat organik ( } \\
\mathrm{KmnO}_{4} \text { ) }\end{array}$ & $\mathrm{Mg} / \mathrm{L}$ & 10 & 4.42 & 4.42 & 3.22 \\
\hline \multicolumn{7}{|c|}{ C. BAKTERIOLOGIS } \\
\hline 1. & Metode & & & 511 & 511 & 511 \\
\hline 2. & Total C.FORM & MPN/100 & & $>240$ & 2 & 2 \\
\hline 3. & C.FORM & MPN/100 & & 38 & 2 & 2 \\
\hline 4. & Kekeruhan air & & & Jernih & Jernih & Jernih \\
\hline 5. & $\begin{array}{l}\text { Status kontaminasi } \\
\text { bakteriologis }\end{array}$ & & & Berisiko & Berisiko & Berisiko \\
\hline
\end{tabular}

Sumber : Analisis Kualitas Air Danau Beratan Tahun 2019

Berdasarkan tabel hasil uji laboratorium di atas, bahwa kualitas air Danau Beratan menunjukan sifat fisik kimia dan biologi yang berbeda, dimana kualitas air Danau Beratan lebih banyak tercemari oleh aspek biologis, seperti: bakteri coliform yang di hasilkan dari kegiatan pembuangan hasil limbah dari pedagang kecil di sekitran Danau Beratan. Selain itu bakteri coliform juga bisa dihasilkan melalui tinja yang di buang oleh masyarakat melalui saluran pipa pembuangan yang berada di sekitar Danau Beratan. berikut data pembuangan dari keempat saluran tersebut.

\section{Simpulan dan saran}

Berdasarkan hasil dan pembahasan yang telah diuraikan mengenai dampak pariwisata terhadap pencemaran air di Danau Beratan Kecamatan Baturiti Kabupaten Tabanan, maka diperoleh simpulan sebagai berikut. Potensi pariwisata di Danau Beratan di hitung dari variabel potesi internal dan eksternal memiliki potensi sedang dimana karakteristik objek wisata Danau Beratan yang menjadi faktor pendorong dan penghambat adalah seimbang atau sama. Secara 
keseluruhan dari hasil uji laboraorium masing-masing sampel air menyatakan bahwa kualitas air masih normal. Ini berarti bahwa pencemaran kualitas air yang berasal dari bahan-bahan kimia yang terdapat di sekitar kawasan objek Danau Beratan masih berada pada batas normal dan belum menunjukan bahwa air mengalami tingkat pencemaran yang tinggi. Sedangkan dari hasil pemeriksaan bakteriologis menunjukan hasil yang berbandig terbalik dengan hasil pemeriksaan kimia maupun fisikanya. Dari hasil pemeriksaan bakteriologis menujukan bahwa air mengalami kontaminasi bakteriologis yang disebabkan oleh adanya bakteri coliform dan coliformh tinja. Konsentrasi pencemaran oleh bakteri coliform ini berpusat pada air Danau yang berada dekat pada aktifitas manusia yaitu titik barat dari danau tersebut yang merupakan sumber aktifitas manusia yang sangat memungkinkan memberikan konnstribusi secara langsung kepada kualitas air dalam bentuk limbah yang terbuang langsung ke air Danau Beratan sehingga air danau mengalami pencemaran. Perkembangan fasilitas pendukung pariwisata saat ini sangat berpengaruh terhadap kualitas air yang ada di Danau Beratan. hal ini terlihat dari adanya zat pencemaran yang mencemari air Danau Beratan seperti limbah dari industri pariwisata yaitu restouran serta limbah yang yang berasal dari aktifitas para pedagang yang berada disepanjang jalan kawasan objek wisata Danau Beratan yang dibuang langsung ke badan air. Selain itu pula juga terdapat limbah bahan bakar dari fasilitas wisata air speedboat yang terbuang langsung ke air danau ataupun para wisatawan yang berkunjung lalu membuang sampah ke danau.

Bedasarkan simpulan di atas, maka saran yang dapat diajukan dalam penelitian ini sebagai berikut. Diharapkan kepada masyarakat atau pelaku pariwisata di kawasan Danau Beratan lebih memperhatikan lingkungan danau sehingga keasrian dan kebersihan khususnya kualitas air danau agar dapat terjaga sehingga nantinya tetap bisa dimanfaatkan untuk pemenuhan kebutuhan air bersih ataupun dengan cara tidak membuang limbah apapun ke danau. Hal ini bertujuan untuk mengurangi pencemaran air yang disumbangkan oleh limbah hasil aktifitas manusia di kawasan danau. Diharapkan agar pemerintah selalu memperhatikan kebijaksaan dalam pengelola lingkungan khususnya dalam pengelolaan lahan di kawasan Danau Beratan agar terjadi keseimbangan pembangunan dikawasan tersebut sehingga nantinya tidak akan merusak ekosistem yang ada. Diharapkan agar pemerintah dan masyarakat selalu berkerjasama memperhatikan pemanfaatan lingkungan danau yang berkawasan lingkungan.

\section{Daftar Rujukan}

Abdurrahman, U. (2006). Kinerja Sistem Lumpur Aktif pada Pengolahan Limbah Cair Laundry. Institut Teknologi Adhi Tama Surabaya.

Anggreswari, N. P. Y. dan A. . R. J. (2018). Pemberdayaan Masyarakat Melalui Pengembangan Objek Wisata Hidden Canyon Beji Guwang. Jurnal Ilmiah Ilmu Sosial, 4(1), 30-40.

Engelen, G. B. (1997). Limnological Study of Logo Di Braies (Pragser Wildsee) Dolomite. Fluktuasi Rerata Tahunan Sebesar 1,2 meter. Kuantitas Air Danau Rerata Tahunan Surplus 0,34 m3/detik. Universitas Gadjah Mada.

Faisal, M. dan D. M. A. (2019). Kualitas Air Pada Sumber Mata Air Di Pura Taman Desa Sanggalangit Sebagai Sumber Air Minum Berbasis Metode Storet. Jurnal Jurusan Pendidikan Geografi Undiksha, 7(2), 74-84.

Frasawi, Edison Stevanus., I. P. A. C. (2018). Partisipasi Masyarakat dalam PengembanganDesa Wisata Ambengan Kecamatan Sukasada. Jurnal Pendidikan Geografi Undiksha, 6(3), 175185.

Hehanussa, P. E. dan G. . H. (2009). Klasifikasi Danau di Indonesia untuk Mitigasi Dampak Perubahan Iklim. Prosiding Konferensi Nasional Danau Indonesia I Jilid 2: Pengelolaan Danau Dan Antisipasi Perubahan Iklim, 298-310. Jakarta: Kementerian Negara Lingkungan Hidup.

Malia, E. L. (2017). Studi Pengelolaan Limbah Bahan Berbahaya dan Beracun Khusus Oli Bekas Pada Bengkel Motor di Kota Makassar. Universitas Hassanuddin.

Manumudhita, I. N. (2002). Penelitian Perubahan Tata Guna Tanah Di Wilayah Sekitar Danau 
Beratan Kabupaten Dati II Tabanan. Provinsi Bali.

Rahadiani, D. I. G. . S. D. I. N. N. (2019). Partisipasi Masyarakat Sekitar Danau Beratan Dalam Konservasi Sumber Daya Air. Spektran, 2(2).

Somantri, L. (2015). Peran lmu Geografi dalam Peningkatan Kecerdasan Ruang Wilayah Indonesia. Prosiding Seminar Nasional. 